\title{
Novel immortal human cell lines reveal subpopulations in the nucleus pulposus
}

\author{
Guus GH van den Akker ${ }^{1,2}$, Don AM Surtel ${ }^{1}$, Andy Cremers ${ }^{1}$, Ricardo Rodrigues-Pinto ${ }^{3,4}$, Stephen M Richardson ${ }^{3}$,
} Judith A Hoyland ${ }^{3}$, Lodewijk W van Rhijn ${ }^{1}$, Tim JM Welting ${ }^{1+}$ and Jan Willem Voncken ${ }^{2^{*+}}$

\begin{abstract}
Introduction: Relatively little is known about cellular subpopulations in the mature nucleus pulposus (NP). Detailed understanding of the ontogenetic, cellular and molecular characteristics of functional intervertebral disc (IVD) cell populations is pivotal to the successful development of cell replacement therapies and IVD regeneration. In this study, we aimed to investigate whether phenotypically distinct clonal cell lines representing different subpopulations in the human NP could be generated using immortalization strategies.
\end{abstract}

Methods: Nondegenerate healthy disc material (age range, 8 to 15 years) was obtained as surplus surgical material. Early passage NP monolayer cell cultures were initially characterized using a recently established NP marker set. NP cells were immortalized by simian virus 40 large T antigen (SV40LTag) and human telomerase reverse transcriptase expression. Immortalized cells were clonally expanded and characterized based on collagen type I, collagen type II, a1 (COL2A1), and SRY-box 9 (SOX9) protein expression profiles, as well as on expression of a subset of established in vivo NP cell lineage markers.

Results: A total of 54 immortal clones were generated. Profiling of a set of novel NP markers (CD24, CA12, PAX1, PTN, FOXF1 and KRT19 mRNA) in a representative set of subclones substantiated successful immortalization of multiple cellular subpopulations from primary isolates and confirmed their NP origin and/or phenotype. We were able to identify two predominant clonal NP subtypes based on their morphological characteristics and their ability to induce SOX9 and COL2A1 under conventional differentiation conditions. In addition, cluster of differentiation 24 (CD24)-negative NP responder clones formed spheroid structures in various culture systems, suggesting the preservation of a more immature phenotype compared to CD24-positive nonresponder clones.

Conclusions: Here we report the generation of clonal NP cell lines from nondegenerate human IVD tissue and present a detailed characterization of NP cellular subpopulations. Differential cell surface marker expression and divergent responses to differentiation conditions suggest that the NP subtypes may correspond to distinct maturation stages and represent distinct NP cell subpopulations. Hence, we provide evidence that the immortalization strategy that we applied is capable of detecting cell heterogeneity in the NP. Our cell lines yield novel insights into NP biology and provide promising new tools for studies of IVD development, cell function and disease.

\section{Introduction}

Degenerative disc disease (DDD) poses a substantial socioeconomic burden in developed countries [1]. Currently, treatment of DDD is primarily aimed at relieving symptoms because effective therapy to delay or prevent DDD is not available.

\footnotetext{
* Correspondence: w.voncken@maastrichtuniversity.nl

${ }^{\dagger}$ Equal contributors

2Department of Molecular Genetics, Maastricht University Medical Centre, Maastricht, the Netherlands

Full list of author information is available at the end of the article
}

The intervertebral disc (IVD) consists of a central gelatinous nucleus pulposus (NP) encircled by an elastic, ligamentous annulus fibrosus (AF) and is flanked superiorly and inferiorly by cartilaginous endplates. NP cells are highly specialized and share some features with articular chondrocytes in terms of aggrecan (ACAN), collagen type II, $\alpha 1$ (COL2A1), and SRY-box 9 (SOX9) protein expression [2]. However, compared to articular cartilage (AC), the NP maintains a unique extracellular matrix (ECM) with a higher glycosaminoglycan to hydroxyproline (GAG/ $\mathrm{OH}$-pro) ratio, and its native cells display distinctive gene 
expression signatures [3-5]. The initial stages of DDD correlate with reduced cellularity, aberrant cell function, loss of proteoglycans and concomitant tissue dehydration [6]. As cells within the IVD are responsible for ECM maintenance and homeostasis, they play an important role in the degenerative process. The findings in an increasing number of studies support the idea that mature NP cells are derived from precursor notochordal cells (NCs), although NP cells differ from NCs morphologically and express different genes (reviewed in [7]). However, it is becoming increasingly clear that the NP comprises multiple cell subpopulations [8-11]. This cellular heterogeneity may reflect different stages of proliferation, differentiation and maturation; however, relatively little is known about these NP cell subpopulations. Successful development of cell replacement therapies and IVD regeneration is crucially dependent on an in-depth understanding of cellular and molecular characteristics of the functional IVD. To accomplish this, access to representative human cell models is pivotal. However, current research on primary cells is hampered by restricted availability of human cells, particularly from nondegenerate discs, where there is a relatively inherent low cellularity within the tissue. In addition, lack of well-defined cellular characteristics and differences in the origin of study material (for example, donor age, IVD degeneration status) underlies experimental variability and thus low reproducibility. To date, a few NP cell lines have been independently generated by Sakai et al. [12] and, more recently, by Liu and co-workers [13].

As no cell lines are available that represent the reported different subpopulations in adult human NP cells, we set out to generate in vitro cell models for human NP cells. Our approach using immortalization, clonal selection and outgrowth allowed us to address NP cell heterogeneity. Here we provide a molecular and cellular characterization of the first immortal human NP cellular subpopulations.

\section{Methods}

Isolation of intervertebral disc cells, cell culture and immortalization

Nondegenerate healthy disc material was obtained as surplus material from correction surgery (Maastricht University Medical Centre Medical Ethical Review Committee (MERC) approval 08-4-028). Under Dutch law, informed patient consent is part of the MERC approval and is not required separately (see Table 1). Determination of the absence of DDD was based on macroscopic examination. Tissue samples were macroscopically dissected by the staff surgeon. Only IVD tissue from the convex side of the scoliotic disc was used for processing. To prevent crosscontamination between IVD-derived tissues, remnant endplate material was completely resected and a broad section of the transition zone extending well into defined
NP tissue or outer AF tissue was removed. NP and AF tissues were stored and processed separately. Tissue was dissected into small pieces and digested overnight with $0.05 \%$ collagenase type II (17101-015; Invitrogen, Carlsbad, CA, USA) in Dulbecco's modified Eagle's medium/Nutrient Mixture F-12 (GlutaMAX DMEM/F-12; Gibco, Grand Island, NY, USA) buffered with 4-(2-hydroxyethyl)1-piperazineethanesulfonic acid at $37^{\circ} \mathrm{C}$ under constant agitation. Isolates were passed through a $70-\mu \mathrm{m}$ cell strainer and collected by centrifugation $(280 \times g, 5$ minutes, Eppendorf centrifuge 5810R) and cultured in maintenance medium (Mmed) (DMEM-F-12/GlutaMAX, 10\% foetal calf serum (DE14-801 F; BioWhittaker, Walkersville, MD, USA), $1 \%$ penicillin-streptomycin (Gibco) and $1 \%$ nonessential amino acids (NEAAs) (Gibco). Cells were seeded at a density of 30,000 cells $/ \mathrm{cm}^{2}$. Upon confluence (passage 0 (P0)), cultures were expanded as pools (1:2 dilutions per passage, until P5) to obtain sufficient material for initial characterization. Monolayer differentiation was induced using an established protocol for articular chondrocytes [14]. A total of 30,000 cells $/ \mathrm{cm}^{2}$ were incubated in differentiation medium (Dmed: DMEM/F-12, 1\% antibiotic/ antimycotic, $1 \%$ insulin/transferrin/sodium selenite (ITS; Invitrogen)), 1\% L-ascorbic acid 2-phosphate deoxycholate (Sigma-Aldrich, St Louis, MO, USA), $1 \mathrm{ng} / \mathrm{ml}$ transforming growth factor $\beta 3$ (TGF $\beta 3$ ) (PHG9305; Gibco) and $1 \%$ NEAA for the indicated time periods. The U$\mathrm{CH} 1$ chordoma cell line (courtesy of S Brüderlein, Ulm, Germany) was grown as previously described [15].

\section{Retroviral transduction and generation of immortal clones}

The simian virus 40 large $\mathrm{T}$ antigen (SV40LTag) and human telomerase reverse transcriptase (hTERT) cDNAs were cloned into pBABE-hygro [16] and pBMN-IRESNEO vectors, respectively. Production of viral particles was performed as described previously [17]. Viral titres were sufficiently high to achieve nearly $100 \%$ infection. Retrovirally transduced P5 AF and NP cells from donors 4 and 5 were selected with $400 \mu \mathrm{g} / \mathrm{ml} \mathrm{G418}$ and $25 \mu \mathrm{g} / \mathrm{ml}$ hygromycin B (PAA Laboratories/GE Healthcare Life Sciences, Somerset, UK). Immediately following selection, clones were generated by plating less than 1 cell (that is, \pm 0.5 ) per well in 96-well plates in reduced selection medium $(200 \mu \mathrm{g} / \mathrm{ml} \mathrm{G418}$ and $12 \mu \mathrm{g} / \mathrm{ml}$ hygromycin B). After 1 week of culture, small colonies became discernible. Culture wells with more than one colony were omitted from further study to ensure single picks. Single clones were expanded under continued antibiotic selection pressure and expanded for three more passages ( $\mathrm{P} 1$ to $\mathrm{P} 4$ ) for cryogenic storage and screening experiments. Selected clones were expanded and remained stable for 8 months or 328 additional population doublings. 
Table 1 Intervertebral disc donor characteristics and clones ${ }^{\mathrm{a}}$

\begin{tabular}{|c|c|c|c|c|c|c|c|c|c|}
\hline \multirow[b]{2}{*}{ Donor } & \multirow[b]{2}{*}{ Sex } & \multirow[b]{2}{*}{ Age $^{b}, y r$} & \multirow[b]{2}{*}{ Medical indication } & \multirow[b]{2}{*}{ Position IVD } & \multirow[b]{2}{*}{$T$ mRNA primary isolates } & \multirow[b]{2}{*}{ NP clones } & \multicolumn{3}{|c|}{ Morphology } \\
\hline & & & & & & & Wave & Cobbl & Tiny \\
\hline$\overline{\mathrm{D} 1}$ & M & 8 & Spina bifida/scoliosis & T11-L4 & Positive & N/A & & & \\
\hline D2 & $\mathrm{F}$ & 13 & Idiopathic scoliosis & L1-L4 & Negative & N/A & & & \\
\hline D3 & M & 14 & Spina bifida/scoliosis & T12-L4 & Negative & N/A & & & \\
\hline D4 & $\mathrm{F}$ & 15 & Idiopathic scoliosis & T7-Т10 & Negative & 34 & 19 & 14 & 1 \\
\hline D5 & M & 13 & Spina bifida/scoliosis & T6-L1 & Negative & 20 & 11 & 7 & 2 \\
\hline
\end{tabular}

${ }^{a}$ IVD, Intervertebral disc; L, Lumbar; N/A, Not applicable; NP, Nucleus pulposus; T, Thoracic. ${ }^{\mathrm{b}}$ Age in years at the time discs were obtained during surgery. Tissues were obtained from young adolescent scoliosis patients who had undergone correction surgery. In contrast to herniated or adult discs, these intervertebral discs showed no signs of degeneration; they had clear, lucid nuclei pulposi that could easily be distinguished from the annulus fibrosis. Each cell isolate (from donors D1 to D5) derived from AF and NP tissue excised at multiple adjacent levels, ranging from T6 to L4 as indicated, in a single individual. The total number of generated clones is indicated in column 'Immortal NP clones', and the amount of cobblestone (Cobbl), wavelike (Wave) and tiny clones is indicated in column 'Clonal morphology'. Brachyury T ( $T$ ) expression was measured in all primary isolates at the mRNA and protein levels; only D1 was found to be positive.

\section{Telomeric repeat amplification protocol}

To measure TERT activity, a telomeric repeat amplification protocol assay was performed according to the manufacturer's instructions (TRAPeze Telomerase Detection Kit; Millipore, Amsterdam, the Netherlands) [18]. Briefly, $1 \mu \mathrm{g}$ of total protein input was used to produce tandem TAAGGG repeats (extension step at $30^{\circ} \mathrm{C}$ for 30 minutes); these repeats were amplified by PCR using telomere-specific primers (30 cycles), which typically generated a ladder of products with 6-bp increments starting at 50 nucleotides (for example, 50, 56, 62, 68).

\section{Aggrecan coating differentiation assays}

To assess NP clonal responses to a relevant proteoglycan in the NP ECM, ACAN was used to coat culture dishes. In brief, we added $5 \mu \mathrm{g}$ of purified bovine ACAN (Sigma-Aldrich A1960) in $200 \mu$ l of solution to 24-well culture plates. The continuously agitated solution was allowed to evaporate overnight at ambient temperature under sterile conditions as described previously [19]. Plates were washed twice with phosphate-buffered saline (PBS), and 200,000 cells/well suspended in Dmed were seeded. Media were changed every other day.

\section{Matrigel cell culture assays}

To assess increases in NP clonal behaviour in a threedimensional environment, we established a Matrigel hydrogel system to support chondrogenesis of articular chondrocytes. Briefly, $90 \mu \mathrm{l}$ of growth factor-reduced Matrigel (BD Biosciences, San Jose, CA, USA) was dispensed into 12-well culture plates (Greiner Bio-One, Monroe, NC, USA). NP cells $(N=68,400)$ were grown for 7 days under conventional (that is, articular chondrocyte) differentiation conditions (in Dmed). mRNA samples were taken at 7 days and isolated using the mirVana mRNA Isolation Kit (Ambion, Austin, TX, USA) for whole RNA extraction according to the manufacturer's instructions.

\section{RNA isolation and quantitative real-time PCR}

For RNA isolation, cells were disrupted in TRIzol reagent (Invitrogen). RNA isolation, RNA quantification (UV) spectrometry (Nanodrop, Thermo Scientific) and cDNA synthesis were performed as described before [20]. Real-time quantitative PCR (RT-qPCR) was performed using Mesagreen qPCR MasterMix Plus for SYBR Green (Eurogentec). Validated primer sets used are depicted in Table 2. An Applied Biosystems ABI PRISM 7700 Sequence Detection System was used for amplification achieved by initial denaturation $95^{\circ} \mathrm{C}$ for 10 minutes followed by 40 cycles of DNA amplification. Data were analysed using the standard curve method and normalized to $\beta$-actin (bACT).

\section{Protein extraction and immunoblotting}

Protein extraction and immunoblotting were performed and analysed as described previously with minor adjustments [21]. For extraction, cells were lysed in radioimmunoprecipitation assay buffer (50 mM Tris, pH 8.0, $150 \mathrm{mM}$ $\mathrm{NaCl}, 0.1 \%$ SDS, $5 \mathrm{mM}$ ethylenediaminetetraacetic acid (EDTA), 0.5\% w/v sodium deoxycholate and 1\% Nonidet P-40) supplemented with protease and phosphatase inhibitors (Roche Diagnostics, Indianapolis, IN, USA). Lysates were sonicated on ice using the Soniprep 150 Plus ultrasonic disintegrator (MSE, London, UK) at amplitude 10 for 14 cycles (1 second on, 1 second off). Insoluble material was removed by centrifugation (10 minutes at $16,000 \times g$ and $\left.4^{\circ} \mathrm{C}\right)$. Protein concentration was determined using a bicinchoninic acid protein assay kit (Pierce/Thermo Scientific, Rockford, IL, USA). Protein samples were separated by SDS-PAGE and immobilized on nitrocellulose membranes. Membranes were blocked for 1 hour in 5\% nonfat dry milk powder (FrieslandCampina, Amersfoort, the Netherlands) at ambient temperature and then incubated with primary antibodies overnight at $4^{\circ} \mathrm{C}$. Antisera used were polyclonal goat anti-COL2A1 (1320-01; Southern Biotech, Birmingham, AL, USA), polyclonal goat collagen type I, $\alpha 1$ (anti-COL1A1) (1310-01; SouthernBiotech), 
Table 2 Quantitative PCR primer list ${ }^{a}$

\begin{tabular}{|c|c|c|c|c|}
\hline Symbol & Gene name & Tissue & Forward primer & Reverse primer \\
\hline ACAN & Aggrecan & $A C, N P$ & GCAGCTGGGCGTTGTCA & TGAGTACAGGAGGCTTGAGGACT \\
\hline CA12 & Carbonic anhydrase XII & NP & ATCCAACTAATGCCACCACCAA & TGAGACCACGAAGAGACTGGCT \\
\hline COLIA1 & Collagen type I, collagen a1 & AF & TGGAGAGTACTGGATTGACCCC & TGCAGAAGACTTTGATGGCATC \\
\hline COL2AI & Collagen type II, collagen a1 & $A C, N P$ & TGGGTGTTCTATTATTTATTGTCTTCCT & GCGTTGGACTCACACCAGTTAGT \\
\hline COMP & Cartilage oligomeric matrix protein & $A C$ & CAAGGCCAACAAGCAGGTTTG & CAGTTATGTTGCCCGGTCTCA \\
\hline CD24 & Cluster of differentiation 24 & NP & CCACGCAGATTTATTCCAGTGA & GCCAACCCAGAGTTGGAAGTAC \\
\hline FOXF1 & Forkhead box F1 & NP & CCCACACAGGAATTCTGCTGA & TTCCСССАСТTСTGCCATT \\
\hline KRT19 & Keratin 19 & $N C, N P$ & GCAGTCACAGCTGAGCATGAA & TCCGTTTCTGCCAGTGTGTCT \\
\hline$P A X 1$ & Paired box 1 & NP & AGAGCCTGACATCGCCTGTTAA & CGCTTTCCTTATTCAGAGGCA \\
\hline PTN & Pleiotrophin & NP & AGAAGCAATTTGGCGCGGA & TTCAGGTCACATTCTCCCCAGG \\
\hline SOX9 & SRY-box 9 & $A C, N P$ & AGTACCCGCACCTGCACAAC & CGCTTCTCGCTCTCGTTCAG \\
\hline$T$ & Brachyury T & NC & CCACCTGCAAATCCTCATCCT & TTGGAGAATTGTTCCGATGAGC \\
\hline
\end{tabular}

${ }^{\mathrm{a} A C}$, Articular cartilage; AF: Annulus fibrosus; NC, Notochordal cell; NP, Nucleus pulposus. The sequences are the validated real-time primer sets used for the indicated genes that were subjected to quantitative PCR analysis. 'Tissue' column lists tissue in which marker expression is reported.

polyclonal goat anti-SOX9 (ab3697; Abcam, Cambridge, $\mathrm{UK})$, rabbit polyclonal antibody against brachyury $\mathrm{T}$ (hereafter 'T') (H-210 and SC-20109; Santa Cruz Biotechnology, Santa Cruz, CA, USA), mouse monoclonal anti-SV40LTag (Pab 108, sc-148; Santa Cruz Biotechnology), rabbit polyclonal anti-TERT (R1187; Acris Antibodies, San Diego, CA, USA), mouse monoclonal $\beta$-actin (clone C4, 08691001; MP Biomedicals, Santa Ana, CA, USA), mouse monoclonal a-tubulin (clone B-5-1-2, T6074; Sigma-Aldrich), rabbit polyclonal KAP-1 (A300-275A; Bethyl Laboratories, Montgomery, TX, USA). Secondary antisera used were polyclonal rabbit anti-goat (P0449; Dako Cytomation, Glostrup, Denmark), rabbit anti-mouse (P0260; Dako) and donkey anti-rabbit (711-035-152; Jackson ImmunoResearch Laboratories, West Grove, PA, USA). Signals were detected using enhanced chemiluminescence (Pierce/Thermo Scientific).

\section{Flow cytometry}

Flow cytometry was performed as described previously [22]. Cell surface markers analysed were cluster of differentiation 44 (CD44), CD73, CD90 and CD105 (Miltenyi Biotec, San Diego, CA, USA); gangliosidase 2 (GD2) (Santa Cruz Biotechnology); and CD24 (BioLegend, San Diego, CA, USA). Briefly, antibody incubation (10 minutes at $4^{\circ} \mathrm{C}$ in the dark) was followed by washes.

\section{Cell proliferation assays}

Cells were seeded at 6,400 cells $/ \mathrm{cm}^{2}$, allowed to attach overnight ( $t 0$; baseline) and grown in 12-well plates for 12 days. At the indicated time points ( $c f$. Figure $2 \mathrm{C}$ ), cells were washed in PBS, fixed in 3.7\% formaldehyde in PBS solution for 10 minutes at ambient temperature and rinsed with demineralized water. Nuclear DNA was stained $(0.1 \%$ Crystal violet, 30 minutes, ambient temperature), after which cells were washed extensively with demineralized water. Crystal violet was extracted at a fixed volume of $10 \%$ acetic acid. Absorbance was determined at $590 \mathrm{~nm}$ (Benchmark microplate reader; Bio-Rad Laboratories, Hercules, CA, USA).

\section{Biochemical matrix assays}

Total sulphated GAG content was determined in papaindigested samples by using 1,9-dimethylmethylene blue stain (DMB) (Polysciences, Eppelheim, Germany) [23]. Briefly, cell cultures were washed with $0.9 \% \mathrm{NaCl}$ and incubated at $60^{\circ} \mathrm{C}$ for 16 hours in digestion buffer $(100 \mathrm{mM}$ sodium phosphate, $\mathrm{pH}$ 6.5, $5 \mathrm{mM}$ L-cysteine $\mathrm{HCl}, 5 \mathrm{mM}$ EDTA) containing 125 to $140 \mu \mathrm{g} / \mathrm{ml}$ papain (Sigma-Aldrich P3125). Samples were collected and centrifuged at $12,000 \mathrm{rpm}$ for 5 minutes, and the supernatants were incubated with DMB solution ( $46 \mu \mathrm{M}$ DMB, $40.5 \mathrm{mM}$ glycine, $40.5 \mathrm{mM} \mathrm{NaCl}, \mathrm{pH} 1.5)$. An absorption ratio of $540 \mathrm{~nm} /$ $595 \mathrm{~nm}$ was determined within 5 to 10 minutes of adding DMB solution. A standard curve of chondroitin sulphate (Sigma-Aldrich) was included as a reference. OH-pro quantification was performed using a chloramine-T assay and compared to a trans-4-hydroxyproline standard essentially as described previously [24]. Both GAG and OH-pro content were normalized against cellular DNA content. DNA concentration in papain-digested samples was determined using SYBR Green stain (Eurogentec, Fremont, CA, USA) as described previously [14]. Quantification of DNA concentration was analysed against a genomic control DNA standard (calf thymus; Invitrogen).

\section{Statistics}

Statistical significance $(P<0.05)$ was determined by twotailed Student's $t$-test. To test for normal distribution of 
input data, D'Agostino-Pearson omnibus normality tests were performed. All quantitative data sets presented passed the normality tests. The results of gene expression analyses are reported as means with standard deviations where indicated. The $P$-values given in the figure legends are for comparisons between AF and NP for all donors combined or between clonal subtypes (NP-R vs NP-nR). $P$-values for every statistical calculation are presented in Additional file 1: Tables S1 to S4.

\section{Results}

Phenotypic characterization of primary nucleus pulposus cultures

Isolated primary NP cells have been reported to display a rounded morphology and AF cells a comparatively more elongated morphology [25,26]. As immortalization procedures and isolation and expansion of cell clones require cells to be adherent, we adapted culture conditions to a monolayer system. Under these adherent growth conditions, primary NP and AF cells both showed a spread-out morphology at early passages (Figure 1A). To validate their NP and AF phenotypes (and hence their tissue origin), we analysed a number of independent primary NP cultures (donors 1 to 5; see Table 1) at different passages for protein and mRNA marker expression (Table 2) and compared them to complementary AF cultures (Figures $1 \mathrm{~B}$ and $1 \mathrm{D}$ to $1 \mathrm{~F}$ ). Primary cultures from two independent donors, D1 (P0) and D2 (P1), showed more prominent COL2A1 mRNA expression in NP cultures and expressed COL1A1 equally in NP and AF cultures (Figure 1B). COL2A1 protein was detectable in one of two low-passage NP isolates, but not in primary AF cells (Figure 1B). COL1A1 protein was clearly detectable in all AF cultures, but was considerably lower in primary NP cells. These findings are consistent with reported differences between AF and NP cells [27].

Cell isolates D4 and D5 were expanded to P5 for comparative analysis and cloning (Figure $1 \mathrm{C}$ ). The chondrocyte phenotype is known to be unstable in vitro [28,29]. We therefore tested the differentiation capacity of primary IVD cell cultures. AF and NP cell isolates (P5) from two independent donors showed low amounts of COL2A1 and comparable COL1A1 protein levels (Figure 1D). Dmed induced SOX9 protein expression in primary NP and AF cultures (Figure 1E). In addition, COL2A1 was induced in Dmed in NP as well as AF isolates. Importantly, COL2A1 induction was clearly more prominent in NP cultures (Figure 1E), whereas COL1A1 expression was higher in AF cells (Figure 1E).

NP marker mRNA analysis for CA12, CD24, FOXF1, $P A X 1, P T N$ and cytokeratin 19 (KRT19) clearly discriminated between AF and NP cultures in samples from three independent donors (Figure 1F). KRT19 mRNA was higher in NP compared to AF cultures (4- to 70-fold), as were CA12 (1.5- to 3-fold), CD24 (2- to 2.5-fold), FOXF1 (1.9- to 2.3-fold), PAX1 (1.2- to 15-fold) and PTN (2- to 3 -fold). These six markers initially appeared stable in pools P0 to P5, although expression diminished thereafter, at P10 (data not shown). Of note, neither $T$ mRNA nor protein was detected in the primary NP isolates of the donors, except for the youngest donor (D1, age 8 years) (Table 1). $T$ is specifically expressed in the notochord and in NCs in the IVD. As such, this finding suggests that the primary isolates that we used for cell line generation were free of NCs. These combined phenotypic analyses confirmed the respective tissues of origin of the primary NP and AF cell isolates and suggest that differentiation capacity was maintained in primary NP cultures. Taken together, these findings provide a solid basis for experimental immortalization and clonal cell line generation.

Isolates from two different donors (D4 and D5) (Table 1) were immortalized at P5 using a combination of retroviral vectors expressing SV40LTag or hTERT. SV40LTag and hTERT expression and/or function were analysed in transduced AF and NP pools (Figures 2A and 2B). Assessment of the proliferative capacity of transduced AF and NP pools revealed that proliferation lifespan was extended well beyond that of the nonimmortalized parental cell pool (Figure 2C). Transduced, G418-resistant AF and NP cells were seeded at low density to allow expansion of single immortal colonies. A more detailed description of the procedure is provided in the Methods section. A detailed characterization of immortal AF clones will be published elsewhere.

Immortal NP clones from each donor exhibited a set of distinct morphologies. During monolayer expansion, 40\% (D4) and 35\% (D5) of the clones showed a 'cobblestone' appearance and 56\% (D4) and 55\% (D5) were organized in wavelike patterns (Figures $3 \mathrm{~A}$ and $3 \mathrm{~B}$ and Table 1). A third, rare clonal phenotype consisted of distinctly smaller cells, denoted as 'tiny (3\% of D4 clones and 10\% of D5 clones) (Figures 3A and 3B). Stimulation with Dmed further emphasized the differences in morphology (Figure 3B, bottom panel). Very low $T$ mRNA expression (on average 100 -fold lower than the U-CH1 positive control), and absence of $\mathrm{T}$ protein indicated that representative clones expressed few if any notochord markers (Figure 3C). The observation that these phenotypic subtypes could be established from two independent donor NP pools strongly suggests that multiple different cell phenotypes coexist in the human NP and that these can be isolated as NP subtypes and propagated as immortal cell lines.

\section{Phenotypic characterization of immortalized nucleus pulposus clones}

We next examined the differentiation capacity of 20 individual immortalized D5 NP clones (Table 1). Expanded clones were induced to differentiate using a standard AC 


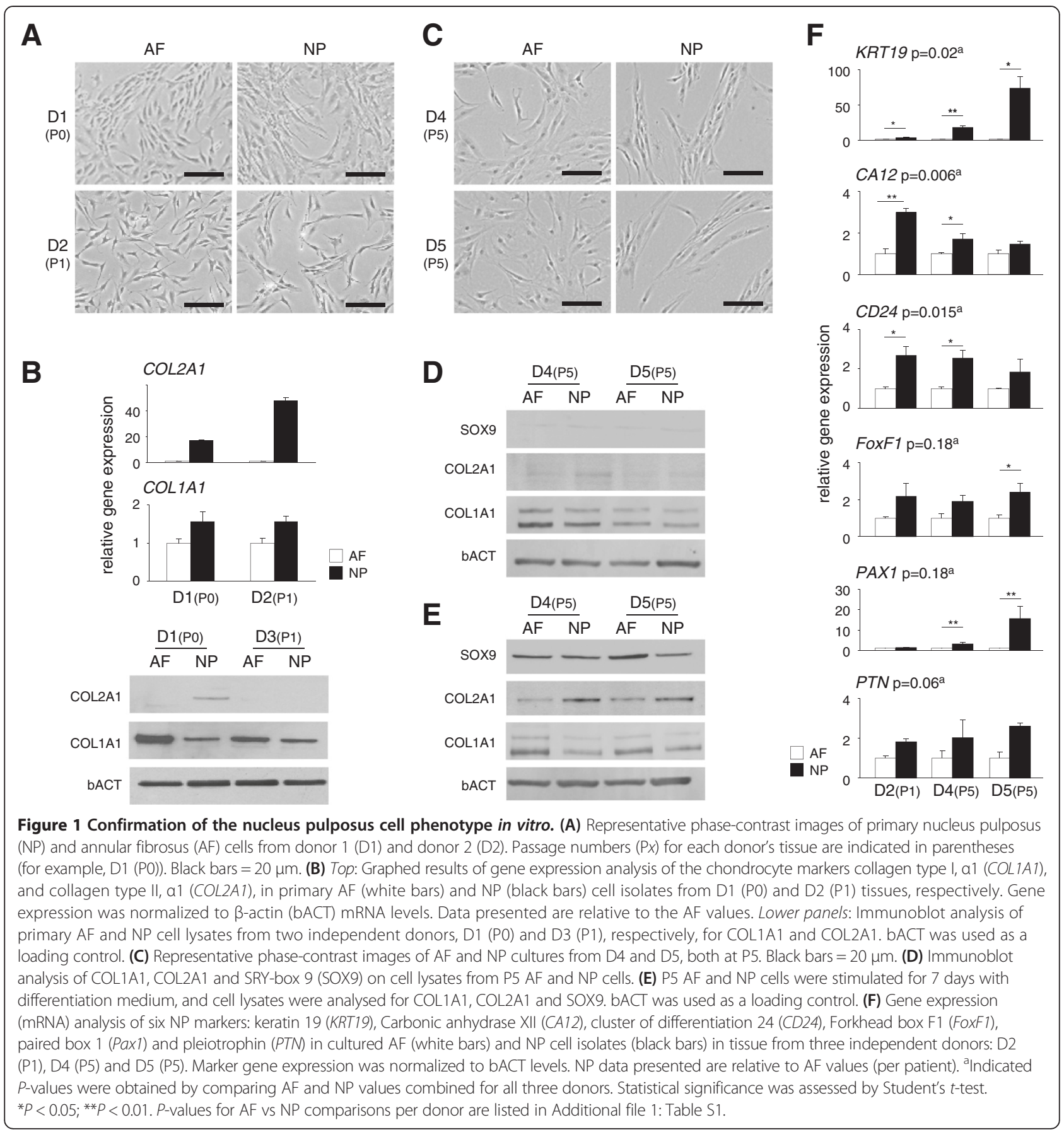

protocol with Dmed, and marker expression was evaluated at the level of proteins (SOX9, COL2A1 and COL1A1).

The majority (90\%) of clones displayed one of two responses based on their ability to undergo chondrogenic differentiation: responder NP (NP-R) clones showed a clear differentiation-dependent induction of SOX9 expression, whereas nonresponder (NP-nR) clones did not (Figure 4A). In NP-R clones, SOX9 induction correlated with COL2A1 induction, whereas this was not the case for NP-nR clones, which expressed higher basal COL2A1 levels at t0) than NP-R clones. COL1A1 protein was detectable in most clones in Mmed and relatively increased in NP-R clones in Dmed compared to NP-nR clones. Of note, the induction profiles correlated perfectly with clonal morphology: All chondrogenic NP-R clones exhibited the wavelike morphology, whereas all NP-nR clones displayed a cobblestone appearance (Figure 4A, lower panels). As the 'tiny' clone morphology did not show a consistent marker expression signature, it was omitted from further analysis. 


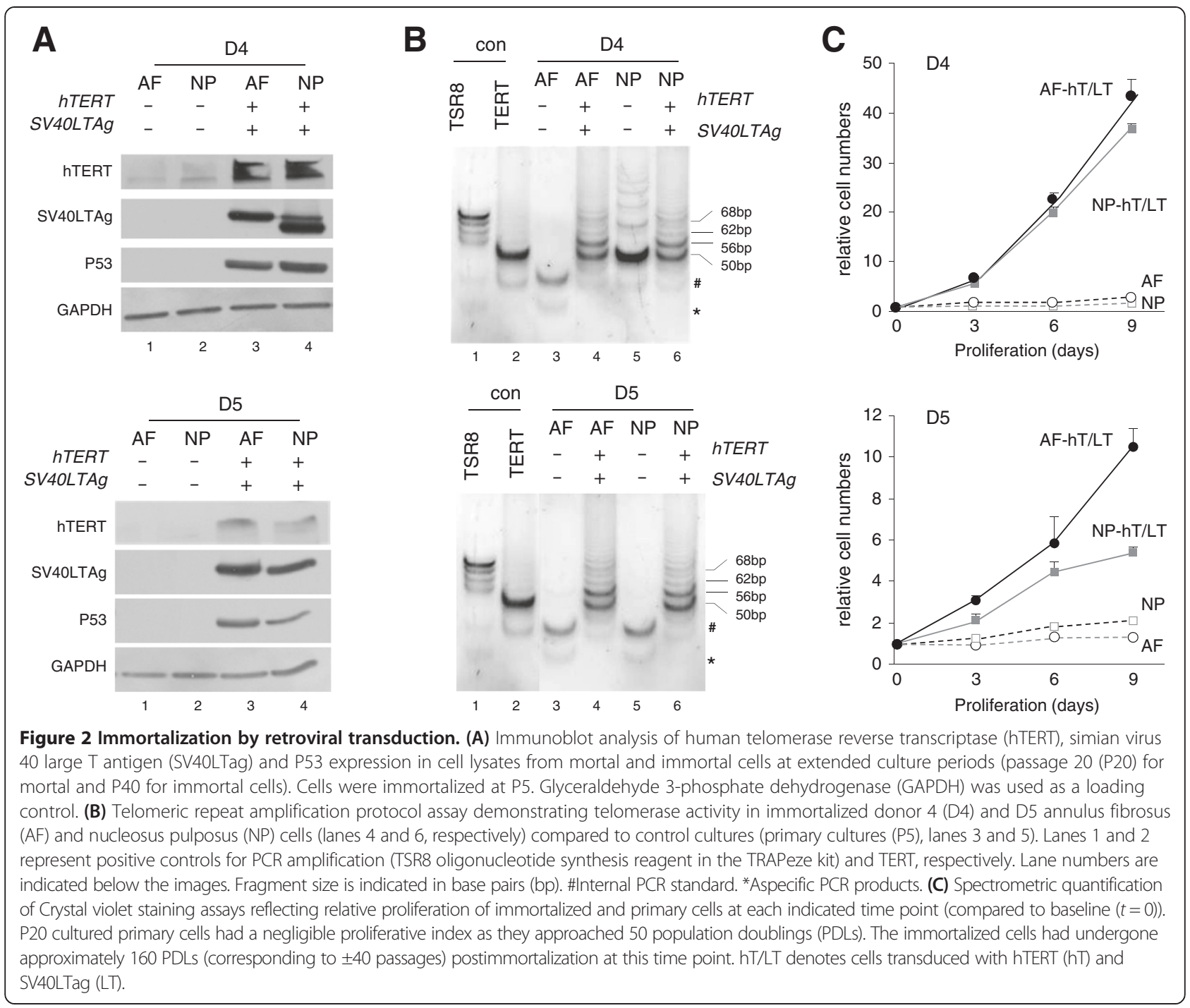

To determine whether any of the NP markers described above could discriminate between the clonal subtypes (NP-R vs nR), we evaluated differences in mRNA levels of KRT19, CA12, CD24, PTN, FOXF1 and PAX1. In addition, we included cartilage oligomeric matrix protein $(C O M P)$, a gene previously shown to be expressed in rat $\mathrm{AC}$ and $\mathrm{NP}$ cells and in human NP cells [30,31]. Comparative gene expression analysis of two groups of six representative chondrogenic NP-R and NP-nR clones revealed a clear segregation between the two subtypes. Of these markers, $C A 12$ and FOXF1 levels were significantly higher at $t 0$ in NP-R clones (Figure 4B; see Additional file 1: Table S2). $C D 24$ showed a trend towards lower expression in NP-R clones under maintenance conditions, whereas COMP mRNA levels tended to be higher in this NP subtype under the same conditions; however, these differences did not reach significance $(P=0.056$ and $P=0.099$, respectively). KRT19, PAX1 and PTN mRNA levels were not significantly different between NP-R and $n R$ clones at t0. Exposing NP subtypes to differentiation conditions induced distinct responses (that is, marker gene expression) between the NP subtypes. CA12 mRNA levels significantly decreased in both NP-R and NP-nR clones, which eliminated the original differences (that is, at $t 0$ ) between these subtypes (7 days in Dmed) (Figure 4B). In contrast, FOXF1 and $C O M P$ significantly changed in NP-R clones, but not in NP-nR clones, in Dmed. Conversely, PAX1 levels significantly dropped in NP-nR clones, but not in NP-R clones, in Dmed. Remarkably, all seven markers tested displayed enhanced differences in expression levels in $\mathrm{NP}-\mathrm{R}$ versus NP-nR clones under Dmed conditions, three of which reached significance $(F O X F 1 \quad(P=0.008), P T N$ $(P=0.01)$ and $\operatorname{COMP}(P=0.02))$. The remaining four markers showed consistent trends (CA12 $(P=0.069), C D 24$ 


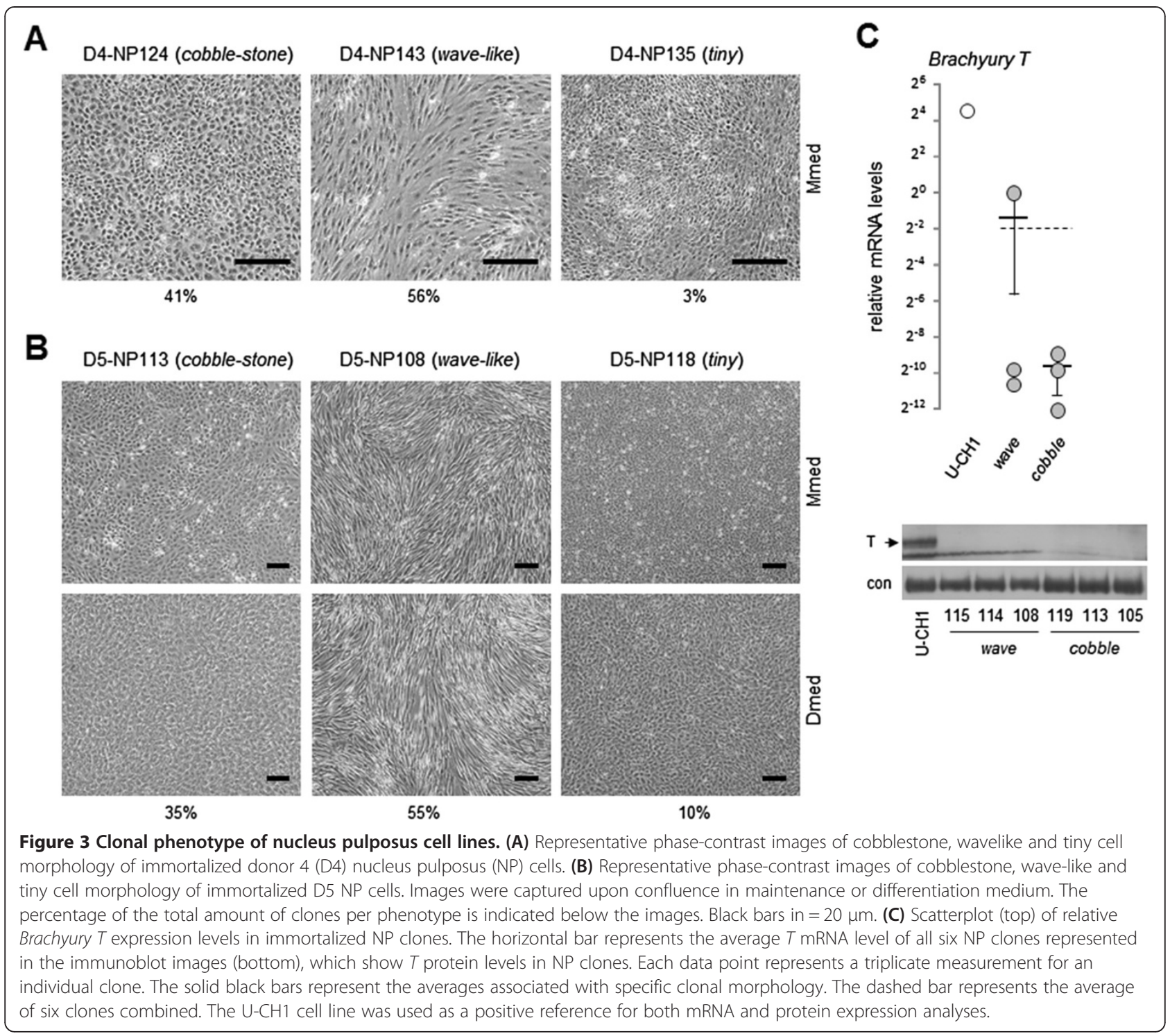

$(P=0.073), P A X 1 \quad(P=0.066)$ and $\operatorname{KRT19}(P=0.056))$ (Figure 4B). CD24 excepted, expression of all markers was reduced in NP-nR clones under these conditions. The induction of important ECM structural proteinencoding mRNAs such as COL2A1 and ACAN was relatively low at the transcriptional level and did not correlate with cell morphology (data not shown).

In summary, the results of our analyses demonstrate clear differentiation-induced COL2A1 and SOX9 protein detection in NP-R clones that correlate well with the described morphological characteristics. The phenotypic differences between NP-R and NP-nR clones are further substantiated by differential NP marker gene expression profiles, under both nondifferentiation and differentiation conditions, and suggest functional phenotypic differences between the immortalized clonal subtypes.

\section{Cell surface characterization of nucleus pulposus clones}

On the basis of the differential marker expression profiles, we hypothesized that NP-R clones represent a NP stem cell progenitor-like phenotype, whereas the NP-nR clones might have been immortalized at a more advanced differentiation or maturation stage. To obtain further support for this supposition, we analysed a number of mesenchymal stem cell (MSC) surface markers (CD73, CD90 and CD105), a disc progenitor marker (GD2) and ontogeny markers (cell adhesion glycoprotein CD24, chondrocytic hyaluronan and collagen receptor CD44) [32-36]. We selected a number of NP-R and NP-nR clones for flow cytometry analysis based on (1) highest SOX9 and COL2A1 protein expression and (2) fold difference in basal KRT19, FOXF1 and CA12 gene expression levels (see Figure 4). We used the cell line $\mathrm{U}-\mathrm{CH} 1$ was used as a reference [15]. 


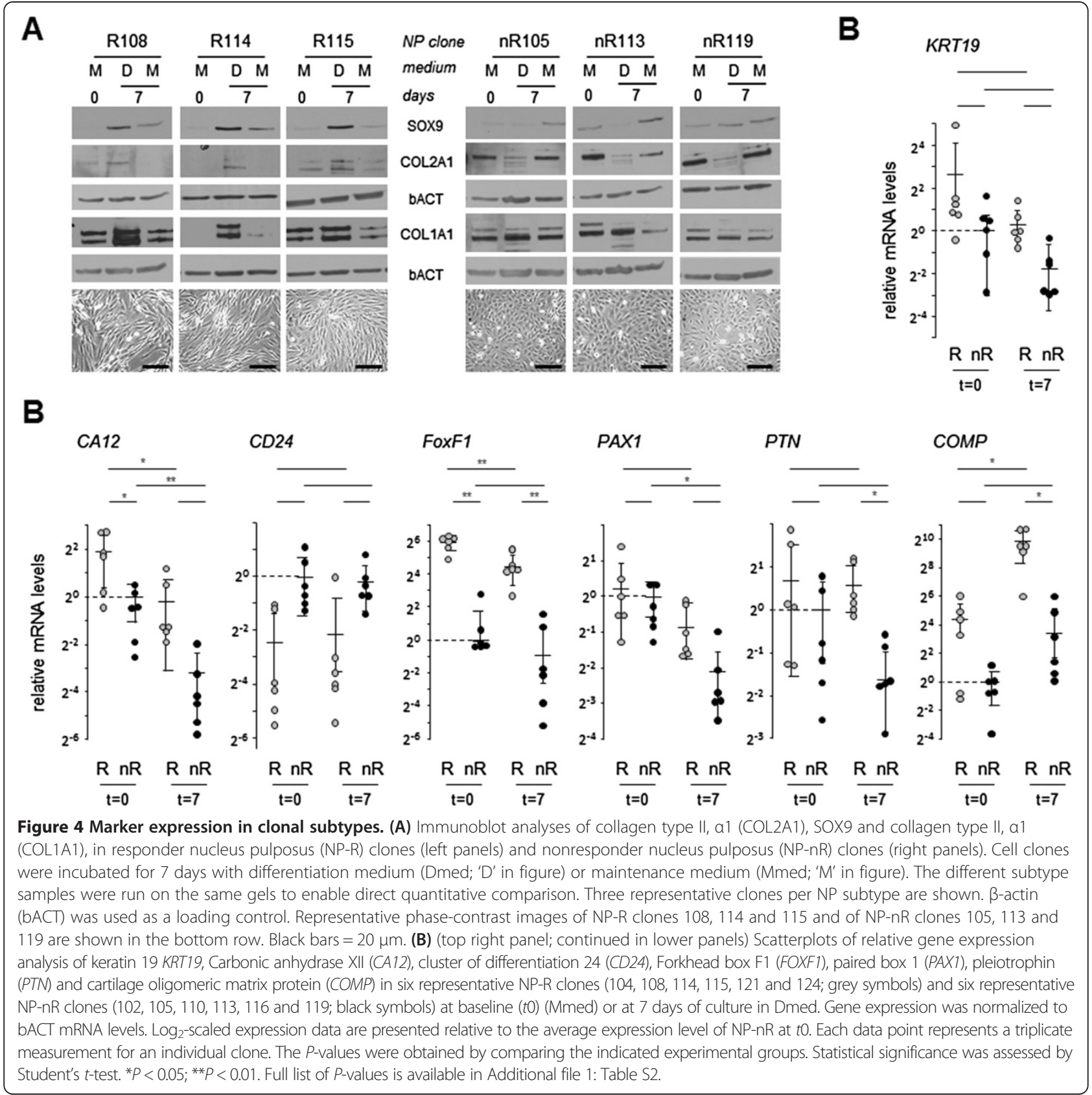

In keeping with the CD24 mRNA measurements, CD24 surface expression was most prominent in NP-nR clones and suggested a more advanced maturation stage (Figures 5A and 5B) [10]. Both NP subtypes were CD44 $4^{+}$ (Figure 5C). In good correlation with their presumed more advanced differentiation stage, NP-nR clones showed more prominent GD2 positivity than NP-R clones under both basal conditions and differentiation conditions Figure 5D) [10]. Both NP clonal subtypes were $\mathrm{CD} 90^{+} / \mathrm{CD} 105^{+} / \mathrm{CD}^{2} 3^{+}$ for these markers (Figure 5C). The observation that all cells were positive for one of the markers in a marker cocktail (CD14, CD20, CD34 and CD45) (data not shown) supports the argument that neither clonal subtype displayed pure MSC properties. Combined, however, the CD marker expression profiles of the NP subtypes do support a mesenchymal origin of the immortal NP clones. Moreover, the CD24/GD2 status discriminates between the NP-R and NP-nR subclones and suggests a difference in differentiation or maturation stage.

\section{Extracellular matrix molecules in nucleus pulposus cell differentiation}

The ECM provides a biological niche that plays a significant role in cellular responses and, as such, in tissue 


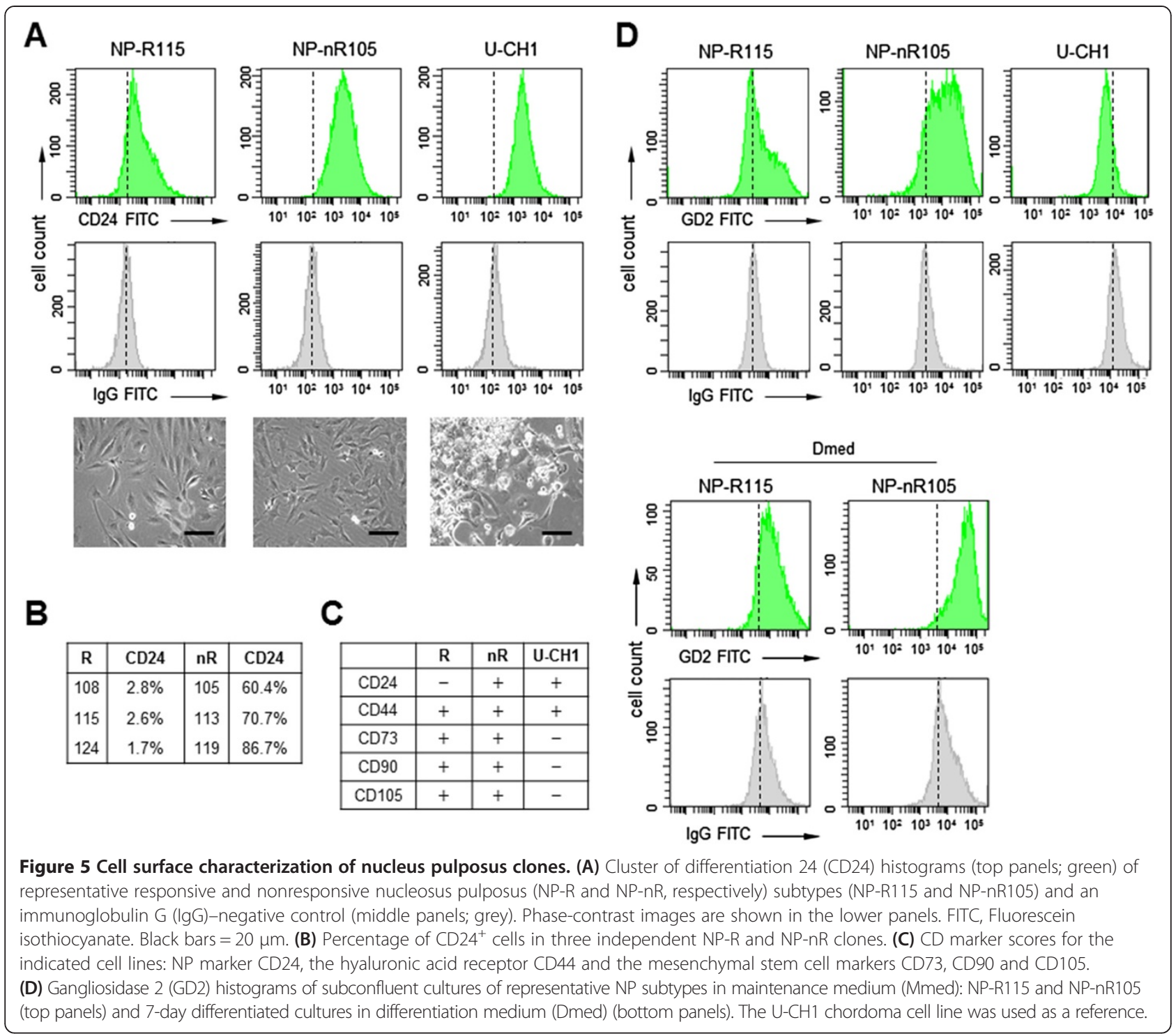

development, homeostasis and repair [37]. For this reason, we measured GAG synthesis and the formation of $\mathrm{OH}$-pro groups in two sets of four independent clones, with each set representing a distinct NP subtype. As neither the exact culture methods nor the optimal composition of Dmed have been established for NP cells, we compared GAG and $\mathrm{OH}$-pro formation in monolayer cultures. In addition, this allowed comparison with data collected to date for the current and other cell lines [14]. We found that, compared to NP-nR clones, NP-R clones produced more (fourfold) GAGs in response to Dmed (Figure 6A). In contrast, culture in Mmed for the same amount of time did not induce GAG production in either subtype (Figure 6A). Although the formation of $\mathrm{OH}$-pro was induced in both NP clonal subtypes in response to Dmed, OH-pro levels reached significantly higher values in NP-R than in NP-nR clones (Figure 6A); no OH-pro was detectable at baseline or in Mmed. Thus, consistent with their distinctive responses to differentiation conditions (for example, induction of SOX9 and COL2A1) (see Figure 4), NP-R clones produced more GAGs and OH-pro than NP-nR.

We next tested the differentiation capacity of NP-R and NP-nR cells on Matrigel, as this was recently shown to support differentiation of induced pluripotent stem cells (iPSCs) to NP-like cells [38]. In addition, we examined the effect of ACAN coating on NP subtype differentiation. ACAN is an important constituent of the NP ECM, and ACAN coating has been applied to assist differentiation of meniscus-derived fibrochondrocytes and MSCs into chondrocyte-like cells $[39,40]$. We cultured NP-R and nR cells in the presence of either Matrigel or ACAN for 3 to 7 days under differentiation conditions and compared induction of SOX9, COL2A1, ACAN and 


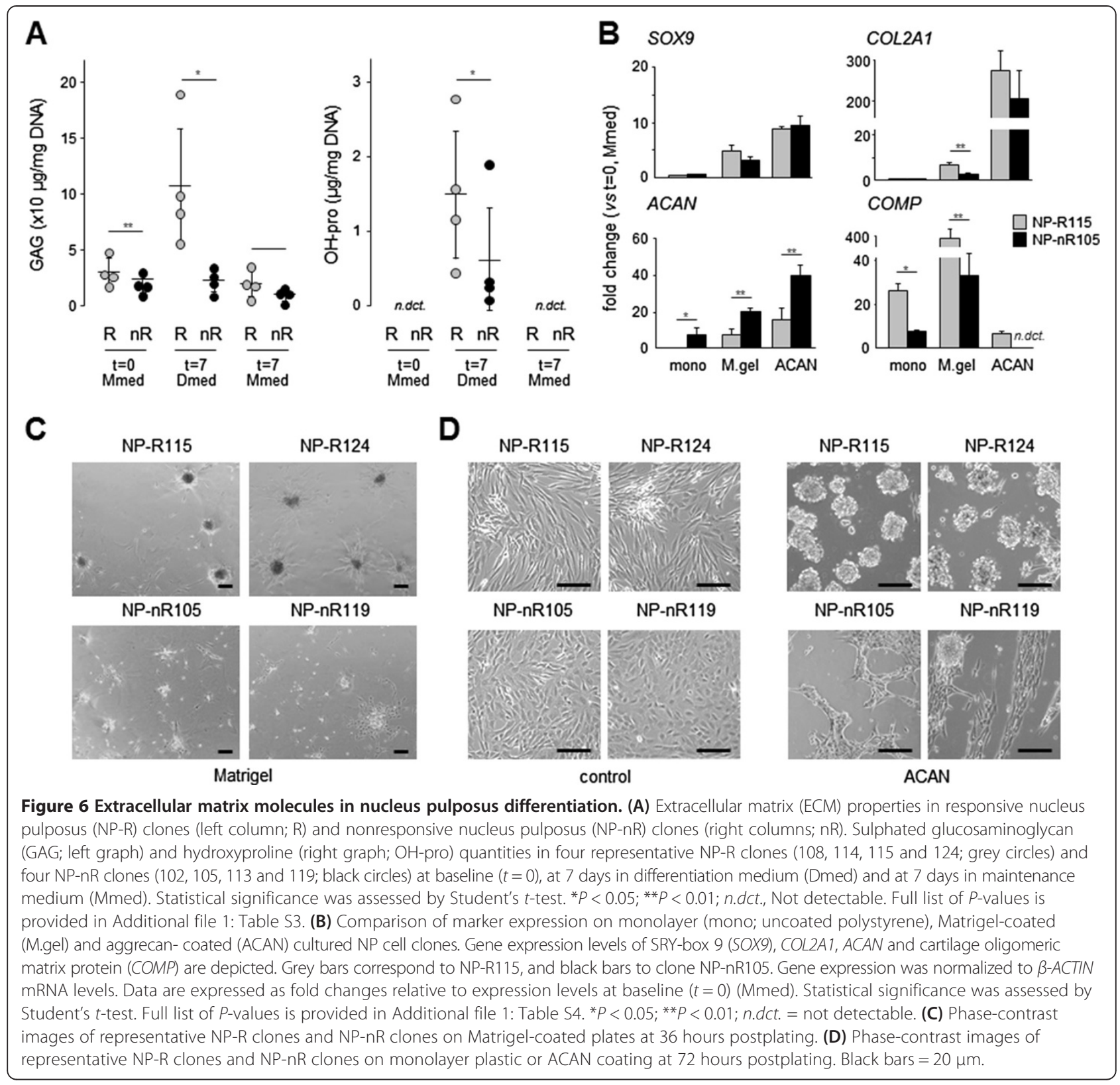

COMP expression. COL1A1 expression was low under all conditions and was not induced (data not shown). SOX9 mRNA levels were comparable between the NP subtypes under all conditions tested. Interestingly, COMP induction was consistently higher in NP-R cells, whereas, conversely, $A C A N$ induction was consistently higher in NP-nR cells, providing further support for the maintenance of distinct functional properties between the NP-R and NP$\mathrm{nR}$ clones. Only on Matrigel was COL2A1 induced significantly greater in NP-R cells (Figure 6B). Remarkably, Matrigel and ACAN coating had dramatic effects on differentiation-induced COMP and COL2A1 expression levels, respectively. These combined results support the idea that ECM is a determining factor in NP cell differentiation responses and suggest that distinct NP cell types differentially respond to the presence of ECM molecules.

The variation in differentiation capacity between NP-R and NP-nR clones suggested a possible difference in differentiation status or maturity between NP cellular subtypes. As relatively immature porcine NC and NP cells were shown to form spheroids on Matrigel [41], we compared NP-R and NP-nR clones for their ability to form spheroids structures under similar conditions. NP-R clones produced spheroid structures on Matrigel, whereas growth of NP-nR clones appeared to be restricted to small adherent colonies (Figure 6C). Remarkably, on ACAN, the NP subtypes revealed similar responses: NP-R clones showed poor attachment 
and readily formed floating spheroids (Figure 6D). Spheroid formation occurred within 24 hours and was most prominent at 72 hours postplating. In contrast, NP-nR clones maintained surface adherence, and spheroid formation (that is, adherence) appeared only sporadically (see, for example, Figure 6D). These collective findings suggest that distinct biological responses are triggered in NP subtypes in the presence of ECM and that Matrigel and ACAN evoke gene-specific transcriptional responses in NP cells compared to standard monolayer differentiation assay conditions.

\section{Discussion}

The application of human IVD material as a potential source of cell lines to date has been limited. Sakai et al. published their first immortalized HNPSV-1 cell line in 2004 [12]. The authors of a recent report [13] described the generation of an NP cell line utilizing a distinct immortalization strategy that we employed in our present study. Despite the low number of studies in which investigators have utilized immortalized NP cell lines, such models provide valuable tools with which to study important aspects, such as the developmental origins of NP, NP cell biology disc degeneration, and can also aid in drug development and drug testing. In this report, we present the generation and thorough initial characterization of novel clonal human NP cell lines. We have established multiple NP cell lines starting from immortalized primary (P5) NP cultures derived from two independent donors. Importantly, analysis of immortal NP clones shows that multiple clonal subtypes can be distinguished based on morphological characteristics, marker gene expression and their diverse responses to differentiation conditions. We also report that ECM-assisted culture models further segregate the NP-R and nR phenotypes based on their spheroidforming capacity in culture.

\section{Nucleus pulposus marker expression}

Several reported NP markers expressed by our immortal cell clones are consistent with a human NP phenotype and hence distinguish our primary NP and AF cultures. NP cell cultures typically synthesize COL2A1, ACAN and SOX9, whereas AF cells predominantly produce COL1A1 and considerably less COL2A1 [42]. Cytokeratin 8 (CK8) and cytokeratin 19 (KRT19) have been suggested as potential NP markers [5,33,43]. Indeed, our NP primary cultures clearly segregated from AF cultures based on KRT19 mRNA expression. In line with the report of cell surface marker CD24 being able to identify the immature NP [44], we found CD24 expression in primary NP cells. Although none of the markers used in the present or previously published analyses are exclusively linked to AF, NP or AC tissue, the consistency of the quantitative differences we detected between AF- and NP-derived cultures further substantiates correspondence to their tissue of origin.

We report here, for the first time to the best of our knowledge, that the significant differences in marker expression between immortal NP subtypes isolated from immortalized primary cultures (CA12, CD24, FOXF1, $P T N, P A X 1$ and $C O M P$ ) discriminate human NP subtypes from two independent donors in primary monolayer cultures. Relevantly, the CA12, CD24, FOXF1 and KRT19 genes have been used successfully to study IVDlike differentiation of MSCs [45]. Of note, throughout the present study, we used differentiation conditions that have previously been established for AC models. As the most optimal conditions for NP cell differentiation are currently unknown, some caution is warranted in direct translation of this data to the in vivo situation. Likewise, numerous animal studies have revealed NP markers that either fail as human NP markers or have not been evaluated in human IVD tissue. Thus, despite recent advances, a consistent definition of a NP marker signature for human cells in vivo is currently lacking $[7,46]$. Investigators in recent gene expression array studies have identified additional markers that distinguish human NP cells from $\mathrm{AC}$ and/or AF cells [3,5]. Similarly, gene expression analysis of distinctive immortalized cellular subtypes may prove useful in refinement of NP marker definition and is also expected to contribute to the development of robust differentiation protocols. Clearly, additional functional analyses are required to determine the role of NP markers in the development and pathology of the IVD.

\section{Nucleus pulposus cell models and differentiation protocols}

Using primary tissue from scoliosis patients as starting material justifies the question whether the primary culture and the immortalized cell cultures may contain degenerate cells. Although we cannot formally exclude this possibility based on our marker analysis, the IVD material we used for these studies was mainly obtained from the convex (that is, noncompressed) side of scoliotic discs. Of note, all available donors were relatively young. In addition, although the number of studies on DDD in the context of scoliosis are limited, DDD is rarely detected at this age, with the exception of cases with associated morbidity (for example, concurrent congenital spinal stenosis, body mass index $>30$, athletics) [47].

It is important to note that the application of immortal cell lines is restricted to in vitro analyses. Experimental application may be limited as a direct consequence of the immortalization procedure itself. For example, SV40LTag interferes with pRB and TP53 function; both proteins are involved in the programming of senescence, which may be relevant for the degeneration process [48-52]. However, the establishment of distinct NP clonal phenotypes 
reported herein (for the first time, to the best of our knowledge) provides access to a source of human NP cell models that will enable us to exploit differences in aspects such as cell surface marker expression to study NP cell biology. These immortalized NP cell models should thus be viewed as powerful complementary models to primary isolates.

The identification of distinct cell phenotypes among our immortalized NP cell clones reflects the cellular heterogeneity in vivo and provides important avenues for further study. Our observations reported herein support the notion that it is possible to fix different epigenetic states (that is, functional cellular heterogeneity) in the NP by means of immortalization procedures. Indeed, others have observed that cellular phenotypes are retained by immortalization [53]. It is relevant to note that NP-R and NP-nR clonal outgrowth may have been subject to selection bias, as integration of retroviral DNA is dependent on active de novo DNA replication; as such, the heterogeneity in NP tissue may not be limited to the two subtypes described herein.

Many differentiation protocols have been optimized for SOX9, COL2A1 or GAG expression in AC cultures, and such protocols have been used to differentiate bone marrow- or adipose tissue-derived MSCs towards an NP-like phenotype [54]. Also, TGF $\beta 3$ supplementation reproducibly promotes collagen and GAG synthesis in primary NP cells $[31,55]$; yet, the exact conditions that faithfully support NP differentiation (and appropriately functioning matrix formation) have been reported throughout the literature to vary and thus appear not to be fully optimized (a parameter that is dependent on consensus definitions of NP phenotypes). Our observation that TGF 33 repressed expression of novel NP markers in primary cells and cell clones is consistent with a recent report [45]. Coculture experiments employing MSCs or conditioned media indicate that as yet unknown factors contribute to NP differentiation and/ or phenotype stabilization [56-59]. The presence of Matrigel or ACAN produced a stronger induction of conventional chondrogenic markers in our clonal NP cell lines. Similarly, ACAN coating has been reported to induce a chondrocyte-like phenotype in primary fibroblasts, which upregulated COL2A1 and SOX9 but not ACAN, and primary meniscus fibrochondrocytes induced ACAN expression but not COL2A1 and SOX9 [19,39]. Also, bone marrow stromal cells express $A C A N$ in response to ACAN coating culture [40]. Remarkably, we found that Matrigel and ACAN enhanced induction of COMP and COL2A1 expression, respectively. Although the mechanism by which ACAN affects differentiation is currently unclear, it is possible that ACAN functions to enhance growth factor signalling, as was recently shown for COMP [60]. In this light, it would be of interest to determine the effect of ACAN coating on NP phenotype stability. Clearly, a much improved definition of NP maintenance and differentiation conditions is needed.

\section{Nucleus pulposus cellular subpopulations}

Evidence for the existence of a progenitor population in the adult human disc in vivo is accumulating $[3,10,61,62]$. The immature NP contains NCs that harbour stem celllike properties, and their lifelong presence in small laboratory animals, in contrast to humans, is thought to support tissue repair and thus prevent disc degeneration $[63,64]$. NCs are replaced by smaller, rounded, chondrocyte-like cells in early human adulthood [65]. As increasing evidence points to an ontogenic relationship between the notochord and the NP, [66], expression analysis of the NC marker $T$ was of relevance to pinpointing the exact nature of our cell cultures. We found that $\mathrm{T}$ mRNA and $\mathrm{T}$ protein expression were very low and undetectable, respectively, in the primary isolates from which the immortal clones were derived. Only the primary NP isolate (D1P0) from the youngest donor (8 years old) had detectable $\mathrm{T}$ mRNA levels (Table 1). These data are consistent with reports that $\mathrm{T}$ expression disappears during human IVD maturation and is virtually undetectable from 10 years of age onwards [7,67]. In keeping with this, the low or absent $\mathrm{T}$ expression in our immortal clones suggests that not NCs, but rather more mature NP cells, were immortalized.

On the basis of their morphology and ability to induce SOX9 and/or COL2A1 expression, we hypothesize that our different immortalized subtypes may represent more differentiated (NP-nR, cobblestone) or more progenitorlike (NP-R, wavelike) cell types. Importantly, we found both subtypes in two independent patient isolates (one male, one female). Both subtypes were $\mathrm{CD} 44^{+}, \mathrm{CD} 73^{+}$, $\mathrm{CD} 90^{+}$and $\mathrm{CD} 105^{+}$, consistent with previously published data [7]. CD24 and GD2 appeared to be more prominently present in our NP-nR clones than in NP-R clones, again supporting NP cell heterogeneity. Future characterization is needed to ascertain the ontogeny of the cloned cells.

The enhanced capacity to form spheroids under Matrigel and ACAN-supported culture conditions favours the notion that the NP-R cells represent a more progenitor or immature cell. Spheroid formation in culture is believed to mirror stem and progenitor capacity in any cell population. Lung-derived bronchospheres (or neurospheres, pancreatic) were previously shown to have stem cell- and progenitor-like characteristics $[68,69]$. Indeed, spheroid formation was also recently used to identify progenitor cell presence in the IVD [10]. The NP-R and NP-nR clones classify as GD2 ${ }^{-} / \mathrm{CD} 24^{-}$and $\mathrm{GD} 2^{+} / \mathrm{CD} 24^{+}$, respectively, and the spheroid-forming capacity of a subset of 
primary NP cells was recently used to propose a differentiation map for Tie2, GD2 and CD24 [10]. Whether the phenotypes (chondrocyte-like, spheroid-forming and/or repopulating cells vs fibroblast-like cells) match our NP-R and NP-nR phenotypes and what role they fulfil in human NP development and disease remain to be determined. At this point, it is also premature to speculate about the ontogeny of these cells.

\section{Conclusions}

We report, for the first time to the best of our knowledge, the generation of phenotypically distinct immortal subclones from primary human NP tissue. Characterization of these clones suggests they correspond to discrete subpopulations in the NP, which differ in terms of morphology, cell surface NP marker expression and differentiation capacity. Interestingly, AC cell lines generated in the 20th century continue to provide important new insights into fundamental issues relating to AC cell biology [70]; thus, similarly immortal NP cell lines are expected to provide vital tools with which to study molecular mechanisms of NP cell ontogeny and cell function in the healthy and diseased IVD. It has become clear that the NP chondrocyte differs from AC; yet, there is currently no comprehensive, descriptive consensus regarding the NP phenotype. We advocate a systematic analytical coverage of isolation procedures, culture conditions and NP marker expression. The environmental interplay between chondrogenic factors and ECM proteins provides clues for further research. How to define the NP cell and how to faithfully mimic the NP microenvironment in vitro remain crucial questions to be resolved in the IVD field. Such issues will determine the success of cell replacement therapy and/or tissue engineering approaches to treating DDD.

\section{Additional file}

Additional file 1: Table S1. Statistical analyses for Figure 1F. Table S2. Statistical analyses for Figure 4B. Table S3. Statistical analyses for Figure 6A. Table S4. Statistical analyses for Figure 6B.

\footnotetext{
Abbreviations

AC: Articular cartilage; ACAN: Aggrecan; AF: Annulus fibrosus; bACT: B-actin; CA12: Carbonic anhydrase XII; CD24: Cluster of differentiation 24; COL1A1: Collagen type I, a1; COL2A1: Collagen type II, a1; COMP: Cartilage oligomeric matrix protein; DDD: Degenerative disc disease; Dmed: Differentiation medium; ECM: Extracellular matrix; FOXF1: Forkhead box F1; GAG: Glucosaminoglycan; GD2: Gangliosidase 2; hTERT: Human telomerase reverse transcriptase; IPSC: Induced pluripotent stem cell; IVD: Intervertebral disc; KRT19: Keratin 19; Mmed: Maintenance medium; NC: Notochordal (precursor) cell; NP: Nucleus pulposus; NP-nR: Nonresponder nucleus pulposus; NP-R: Responder nucleosus pulposus; OH-pro: Hydroxyproline; PAX1: Paired box 1; pRB: Retinoblastoma protein; P: Passage number; PTN: Pleiotrophin; RT-qPCR: Real-time quantitative polymerase chain reaction; SOX9: SRY-box 9; SV40LTag: Simian virus 40 large T antigen; T: Brachyury T; Tie2: Angiopoietin-1, tyrosine kinase receptor 2; TP53: Transforming protein 53.
}

\section{Competing interests}

This research forms part of BMM-IDiDAS P2.01 project ('Biomaterials for Diseases of the Intervertebral Disc', a research programme of the BioMedical Materials Institute), which is cofunded by the Dutch Ministry of Economic Affairs, Agriculture and Innovation.

\section{Authors' contributions}

GGHA was responsible for study design; performed all tissue sample preparation, immortalization, molecular studies data analysis; and drafted the manuscript. DAMS, AC, RRP and SMR helped in study coordination, analysis and interpretation and presentation of the data. JAH, LR, TJMW and JWV conceived the study, secured funding, participated in study design and coordination, analysed the results and cowrote the manuscript. All authors read and approved the final manuscript.

\section{Acknowledgements}

The authors thank R Bernards (Netherlands Cancer Institute (NKI), Amsterdam, the Netherlands) for hTERT cDNA, S Brüderlein (University of Ulm, Germany) for the U-CH1 cell line, K Ito (Eindhoven University of Technology, the Netherlands) for useful discussions and sharing of protocols, R Bank (University of Groningen, the Netherlands) for suggestions on collagen detection and P Willems (Maastricht University Medical Centre, the Netherlands) for medical ethics reflections. Approval of all experimental sections of the present study and informed consent for publication of patient details and accompanying images were obtained as an integral part of approval 08-4-028 from Maastricht University Medical Centre/Maastricht Education and Research Centre. The approval is held by the authors and is available for review by the Editor-in-Chief of this journal. Funding was received from grant LLP14 from the Dutch Arthritis Foundation (to JWV and LWVR) and by a grant from the BMM-IDiDAS project (to LWVR and TJMW). RRP is supported by a grant from the Gulbenkian Programme for Advanced Medical Education, which is sponsored by the Calouste Gulbenkian Foundation, the Champalimaud Foundation, the Ministry of Health of Portugal and the Foundation for Science of Technology; and also by the Portuguese Association of the Pharmaceutical Industry.

\section{Author details}

'Department of Orthopaedic Surgery, Maastricht University Medical Centre, Maastricht, Postbox 616, 6200 MD, the Netherlands. ${ }^{2}$ Department of Molecular Genetics, Maastricht University Medical Centre, Maastricht, the Netherlands. ${ }^{3}$ Centre for Regenerative Medicine, Institute of Inflammation and Repair, University of Manchester, Oxford Road, Manchester M13 9PL, UK. ${ }^{4}$ Department of Orthopaedics, Central Hospital of Porto-St Anthony Hospital, Porto, Portugal.

Received: 27 August 2013 Accepted: 19 June 2014

Published: 27 June 2014

\section{References}

1. Dagenais S, Caro J, Haldeman S: A systematic review of low back pain cost of illness studies in the United States and internationally. Spine J 2008, 8:8-20.

2. Sive JI, Baird P, Jeziorsk M, Watkins A, Hoyland JA, Freemont AJ: Expression of chondrocyte markers by cells of normal and degenerate intervertebral discs. Mol Pathol 2002, 55:91-97.

3. Minogue BM, Richardson SM, Zeef LAH, Freemont AJ, Hoyland JA: Characterization of the human nucleus pulposus cell phenotype and evaluation of novel marker gene expression to define adult stem cell differentiation. Arthritis Rheum 2010, 62:3695-3705.

4. Mwale F, Masuda K, Pichika R, Epure L, Yoshikawa T, Hemmad A, Roughley $P$, Antoniou J: The efficacy of Link $N$ as a mediator of repair in a rabbit model of intervertebral disc degeneration. Arthritis Res Ther 2011, 13:R120.

5. Rutges J, Creemers LB, Dhert W, Milz S, Sakai D, Mochida J, Alini M, Grad S: Variations in gene and protein expression in human nucleus pulposus in comparison with annulus fibrosus and cartilage cells: potential associations with aging and degeneration. Osteoarthritis Cartilage 2009, 18:416-423.

6. Urban JP, Roberts S: Degeneration of the intervertebral disc. Arthritis Res Ther 2003, 5:120-130.

7. Pattappa G, Li Z, Peroglio M, Wismer N, Alini M, Grad S: Diversity of intervertebral disc cells: phenotype and function. J Anat 2012, 221:480-496. 
8. Goldring MB, Birkhead JR, Suen LF, Yamin R, Mizuno S, Glowacki J, Arbiser JL, Apperley JF: Interleukin-1 $\beta$-modulated gene expression in immortalized human chondrocytes. J Clin Invest 1994, 94:2307-2316.

9. Risbud M, Guttapalli A, Tsai T, Lee J, Danielson K, Vaccaro A, Albert T, Gazit Z, Gazit D, Shapiro I: Evidence for skeletal progenitor cells in the degenerate human intervertebral disc. Spine 2007, 32:2537-2544.

10. Sakai D, Nakamura Y, Nakai T, Mishima T, Kato S, Grad S, Alini M, Risbud MV, Chan D, Cheah KSE, Yamamura K, Masuda K, Okano H, Ando K, Mochida J: Exhaustion of nucleus pulposus progenitor cells with ageing and degeneration of the intervertebral disc. Nat Commun 2012, 3:1264.

11. Weiler C, Nerlich A, Schaaf R, Bachmeier B, Wuertz K, Boos N: Immunohistochemical identification of notochordal markers in cells in the aging human lumbar intervertebral disc. Eur Spine J 2010, 19:1761-1770.

12. Sakai D, Mochida J, Yamamoto Y, Toh E, Iwashina T, Miyazaki T, Inokuchi S, Ando K, Hotta T: Immortalization of human nucleus pulposus cells by a recombinant SV40 adenovirus vector: establishment of a novel cell line for the study of human nucleus pulposus cells. Spine (Phila Pa 1976) 2004, 29:1515-1523.

13. Liu MC, Chen WH, Wu LC, Hsu WC, Lo WC, Yeh SD, Wang MF, Zeng R, Deng WP: Establishment of a promising human nucleus pulposus cell line for intervertebral disc tissue engineering. Tissue Eng Part C Methods 2013, 20:1-10.

14. Caron MMJ, Emans PJ, Coolsen MME, Voss L, Surtel DAM, Cremers A, van Rhijn LW, Welting TJM: Redifferentiation of dedifferentiated human articular chondrocytes: comparison of 2D and 3D cultures. Osteoarthritis Cartilage 2012, 20:1170-1178.

15. Scheil S, Brüderlein S, Liehr T, Starke H, Herms J, Schulte M, Möller P: Genome-wide analysis of sixteen chordomas by comparative genomic hybridization and cytogenetics of the first human chordoma cell line, U-CH1. Genes Chromosomes Cancer 2001, 32:203-211.

16. Morgenstern JP, Land H: Advanced mammalian gene transfer: high titre retroviral vectors with multiple drug selection markers and a complementary helper-free packaging cell line. Nucleic Acids Res 1990, 18:3587-3596.

17. Kinsella T, Nolan G: Episomal vectors rapidly and stably produce high-titer recombinant retrovirus. Hum Gene Ther 1996, 7:1405-1413.

18. Piatyszek M, Kim N, Weinrich S, Hiyama K, Hiyama E, Wright W, Shay J: Detection of telomerase activity in human cells and tumors by a telomeric repeat amplification protocol (TRAP). Methods Cell Sci 1995, 17:1-15.

19. French MM, Smith SE, Akanbi K, Sanford T, Hecht J, Farach-Carson MC, Carson DD: Expression of the heparan sulfate proteoglycan, perlecan, during mouse embryogenesis and perlecan chondrogenic activity in vitro. J Cell Biol 1999, 145:1103-1115.

20. Welting $T$, Caron M, Emans $P$, Janssen M, Sanen $K$, Coolsen M, Voss L, Surtel D, Cremers A, Voncken J, van Rhijn LW: Inhibition of cyclooxygenase- 2 impacts chondrocyte hypertrophic differentiation during endochondral ossification. Eur Cell Mater 2011, 22:420-437.

21. Prickaerts $P$, Niessen $H$, Mouchel-Vielh $E$, Dahlmans $V$, van den Akker $G$ Geijselaers C, Adriaens M, Spaapen F, Takihara Y, Rapp U, Peronnet F, Voncken JW: MK3 controls Polycomb target gene expression via negative feedback on ERK. Epigenetics Chromatin 2012, 5:12.

22. Meek B, Van Elssen CHMJ, Huijskens MJAJ, van der Stegen SJC, Tonnaer S, Lumeij SBJ, Vanderlocht J, Kirkland MA, Hesselink R, Germeraad WTV, Bos GMJ: T cells fail to develop in the human skin-cell explants system; an inconvenient truth. BMC Immuno/ 2011, 12:17.

23. Farndale RW, Buttle DJ, Barrett AJ: Improved quantitation and discrimination of sulphated glycosaminoglycans by use of dimethylmethylene blue. Biochim Biophys Acta 1986, 883:173-177.

24. Huszar G, Maiocco J, Naftolin F: Monitoring of collagen and collagen fragments in chromatography of protein mixtures. Anal Biochem 1980, 105:424-429.

25. Kluba T, Niemeyer T, Gaissmaier C, Grunder T: Human anulus fibrosis and nucleus pulposus cells of the intervertebral disc: effect of degeneration and culture system on cell phenotype. Spine 2005, 30:2743-2748.

26. Wang J, Baer A, Kraus $V$, Setton L: Intervertebral disc cells exhibit differences in gene expression in alginate and monolayer culture. Spine 2001, 26:1747-1751.

27. Clouet J, Vinatier C, Merceron C, Pot-Vaucel M, Hamel O, Weiss P, Grimandi G, Guicheux J: The intervertebral disc: from pathophysiology to tissue engineering. Joint Bone Spine 2009, 76:614-618.
28. Benya PD, Padilla SR, Nimni ME: Independent regulation of collagen types by chondrocytes during the loss of differentiated function in culture. Cell 1978, 15:1313-1321.

29. von der Mark K, Gauss V, von der Mark H, Müller P: Relationship between cell shape and type of collagen synthesised as chondrocytes lose their cartilage phenotype in culture. Nature 1977, 267:531-532.

30. Lee CR, Sakai D, Nakai T, Toyama K, Mochida J, Alini M, Grad S: A phenotypic comparison of intervertebral disc and articular cartilage cells in the rat. Eur Spine J 2007, 16:2174-2185.

31. Haberstroh K, Enz A, Zenclussen ML, Hegewald AA, Neumann K, Abbushi A, Thomé C, Sittinger M, Endres M, Kaps C: Human intervertebral disc-derived cells are recruited by human serum and form nucleus pulposus-like tissue upon stimulation with TGF- $\beta 3$ or hyaluronan in vitro. Tissue Cell 2009, 41:414-420

32. Dominici M, Le Blanc K, Mueller I, Slaper-Cortenbach I, Marini F, Krause D, Deans R, Keating A, Prockop D, Horwitz E: Minimal criteria for defining multipotent mesenchymal stromal cells: the International Society for Cellular Therapy position statement. Cytotherapy 2006, 8:315-317.

33. Fujita N, Miyamoto T, Imai J, Hosogane N, Suzuki T, Yagi M, Morita K, Ninomiya K, Miyamoto K, Takaishi H, Matsumoto M, Morioka H, Yabe H, Chiba K, Watanabe S, Toyama Y, Suda T: CD24 is expressed specifically in the nucleus pulposus of intervertebral discs. Biochem Biophys Res Commun 2005, 338:1890-1896.

34. Stevens JW, Kurriger GL, Carter AS, Maynard JA: CD44 expression in the developing and growing rat intervertebral disc. Dev Dyn 2000, 219:381-390.

35. Tang $X$, Jing $L$, Chen J: Changes in the molecular phenotype of nucleus pulposus cells with intervertebral disc aging. PLoS One 2012, 7:e52020.

36. Woods A, Wang G, Beier F: Regulation of chondrocyte differentiation by the actin cytoskeleton and adhesive interactions. J Cell Physio/ 2007, 213:1-8.

37. Sivan SS, Hayes AJ, Wachtel E, Caterson B, Merkher Y, Maroudas A, Brown S, Roberts S: Biochemical composition and turnover of the extracellular matrix of the normal and degenerate intervertebral disc. Eur Spine J 2014, 23:344-353.

38. Chen J, Lee EJ, Jing L, Christoforou N, Leong KW, Setton LA: Differentiation of mouse induced pluripotent stem cells (iPSCs) into nucleus pulposus-like cells in vitro. PLoS One 2013, 8:e75548.

39. Gunja N, Athanasiou K: Passage and reversal effects on gene expression of bovine meniscal fibrochondrocytes. Arthritis Res Ther 2007, 9:R93.

40. Lim JJ, Scott L, Temenoff JS: Aggregation of bovine anterior cruciate ligament fibroblasts or marrow stromal cells promotes aggrecan production. Biotechnol Bioeng 2011, 108:151-162.

41. Gilchrist $C L$, Darling EM, Chen J, Setton LA: Extracellular matrix ligand and stiffness modulate immature nucleus pulposus cell-cell interactions. PLOS One 2011, 6:e27170

42. Mwale F, Roughley P, Antoniou J: Distinction between the extracellular matrix of the nucleus pulposus and hyaline cartilage: a requisite for tissue engineering of intervertebral disc. Eur Cell Mater 2004, 8:58-64.

43. Gilson A, Dreger M, Urban J: Differential expression level of cytokeratin 8 in cells of the bovine nucleus pulposus complicates the search for specific intervertebral disc cell markers. Arthritis Res Ther 2010, 12:R24

44. Chen J, Jing L, Gilchrist C, Richardson W, Fitch R, Setton L: Expression of laminin isoforms, receptors and binding proteins unique to nucleus pulposus cells of immature intervertebral disc. Connect Tissue Res 2009, 50:294-306.

45. Stoyanov J, Gantenbein-Ritter B, Bertolo A, Aebli N, Baur M, M Alini M, Grad S: Role of hypoxia and growth and differentiation factor-5 on differentiation of human mesenchymal stem cells towards intervertebral nucleus pulposus-like cells. Eur Cell Mater 2011, 21:533-547.

46. Rodrigues-Pinto R, Richardson SM, Hoyland JA: Identification of novel nucleus pulposus markers: Interspecies variations and implications for cell-based therapies for intervertebral disc degeneration. Bone Joint Res 2013, 2:169-178.

47. Dimar JR 2nd, Glassman SD, Carreon LY: Juvenile degenerative disc disease: a report of 76 cases identified by magnetic resonance imaging. Spine J 2007, 7:332-337.

48. Zhao CQ, Wang LM, Jiang LS, Dai LY: The cell biology of intervertebral disc aging and degeneration. Ageing Res Rev 2007, 6:247-261.

49. Roberts S, Evans EH, Kletsas D, Jaffray DC, Eisenstein SM: Senescence in human intervertebral discs. Eur Spine J 2006, 15:S312-S316. 
50. Le Maitre CL, Freemont AJ, Hoyland JA: Accelerated cellular senescence in degenerate intervertebral discs: a possible role in the pathogenesis of intervertebral disc degeneration. Arthritis Res Ther 2007, 9:R45.

51. Kim KW, Chung HN, Ha KY, Lee JS, Kim YY: Senescence mechanisms of nucleus pulposus chondrocytes in human intervertebral discs. Spine $J$ 2009, 9:658-666.

52. Rodier F, Campisi J: Four faces of cellular senescence. J Cell Biol 2011, 192:547-556.

53. Lehmann HC, Chen W, Mi R, Wang S, Liu Y, Rao M, Hoke A: Human Schwann cells retain essential phenotype characteristics after immortalization. Stem Cells Dev 2012, 21:423-431.

54. Mern DS, Beierfuß A, Thomé C, Hegewald AA: Enhancing human nucleus pulposus cells for biological treatment approaches of degenerative intervertebral disc diseases: a systematic review. J Tissue Eng Regen Med. in press. doi:10.1002/term.1583.

55. Risbud M, Albert T, Guttapalli A, Vresilovic E, Hillibrand A, Vaccaro A, Shapiro I: Differentiation of mesenchymal stem cells towards a nucleus pulposus-like phenotype in vitro: implications for cell-based transplantation therapy. Spine 2004, 29:2637-2632.

56. Strassburg S, Richardson SM, Freemont AJ, Hoyland JA: Co-culture induces mesenchymal stem cell differentiation and modulation of the degenerate human nucleus pulposus cell phenotype. Regen Med 2010, 5:701-711.

57. Svanvik T, Henriksson $H$, Karlsson C, Hagman M, Lindahl A, Brisby $H$ : Human disk cells from degenerated disks and mesenchymal stem cells in co-culture result in increased matrix production. Cells Tissues Organs 2011, 191:2-11.

58. Purmessur D, Schek R, Abbott R, Ballif B, Godburn K, latridis J: Notochordal conditioned media from tissue increases proteoglycan accumulation and promotes a healthy nucleus pulposus phenotype in human mesenchymal stem cells. Arthritis Res Ther 2011, 13:R81.

59. Richardson SM, Walker RV, Parker S, Rhodes NP, Hunt JA, Freemont AJ, Hoyland JA: Intervertebral disc cell-mediated mesenchymal stem cell differentiation. Stem Cells 2006, 24:707-716.

60. Haudenschild DR, Hong E, Yik JHN, Chromy B, Mörgelin M, Snow KD, Acharya C, Takada Y, Di Cesare PE: Enhanced activity of transforming growth factor $\beta 1$ (TGF- $\beta 1$ ) bound to cartilage oligomeric matrix protein. J Biol Chem 2011, 286:43250-43258.

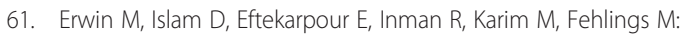
Intervertebral disc-derived stem cells: implications for regenerative medicine and neural repair. Spine 2013, 38:211-216.

62. Sharp C, Roberts S, Evans H, Brown S: Disc cell clusters in pathological human intervertebral discs are associated with increased stress protein immunostaining. Eur Spine J 2009, 18:1587-1594.

63. Aguiar DJ, Johnson SL, Oegema TR: Notochordal cells interact with nucleus pulposus cells: regulation of proteoglycan synthesis. Exp Cell Res 1999, 246:129-137.

64. Bray JP, Burbidge HM: The canine intervertebral disk. Part two: degenerative changes - nonchondrodystrophoid versus chondrodystrophoid disks. J Am Anim Hosp Assoc 1998, 34:135-144.

65. Trout JJ, Buckwalter JA, Moore KC, Landas SK: Ultrastructure of the human intervertebral disc. I. Changes in notochordal cells with age. Tissue Cell 1982, 14:359-369.

66. Minogue BM, Richardson SM, Zeef LA, Freemont AJ, Hoyland JA: Transcriptional profiling of bovine intervertebral disc cells: implications for identification of normal and degenerate human intervertebral disc cell phenotypes. Arthritis Res Ther 2010, 12:R22.

67. Kregar Velikonja N, Urban J, Fröhlich M, Neidlinger-Wilke C, Kletsas D, Potocar U, Turner S, Roberts S: Cell sources for nucleus pulposus regeneration. Eur Spine J 2014, 23:364-374.

68. Huang GS, Dai LG, Yen BL, Hsu SH: Spheroid formation of mesenchymal stem cells on chitosan and chitosan-hyaluronan membranes. Biomaterials 2011, 32:6929-6945.
69. Tesei A, Zoli W, Arienti C, Storci G, Granato AM, Pasquinelli G, Valente S, Orrico C, Rosetti M, Vannini I, Dubini A, Dell'Amore D, Amadori D, Bonafè M: Isolation of stem/progenitor cells from normal lung tissue of adult humans. Cell Prolif 2009, 42:298-308.

70. Lin Z, Willers C, Xu J, Zheng MH: The chondrocyte: biology and clinical application. Tissue Eng 2006, 12:1971-1984.

doi:10.1186/ar4597

Cite this article as: van den Akker et al:: Novel immortal human cell lines reveal subpopulations in the nucleus pulposus. Arthritis Research \& Therapy 2014 16:R135.

\section{Submit your next manuscript to BioMed Central and take full advantage of:}

- Convenient online submission

- Thorough peer review

- No space constraints or color figure charges

- Immediate publication on acceptance

- Inclusion in PubMed, CAS, Scopus and Google Scholar

- Research which is freely available for redistribution
C Biomed Central 